\title{
Defining parasite biodiversity at high latitudes of North America: new host and geographic records for Onchocerca cervipedis (Nematoda: Onchocercidae) in moose and caribou
}

Guilherme G Verocai ${ }^{1 *}$, Manigandan Lejeune ${ }^{2}$, Kimberlee B Beckmen ${ }^{3}$, Cyntia K Kashivakura', Alasdair M Veitch ${ }^{4}$, Richard A Popko ${ }^{4}$, Carmen Fuentealba ${ }^{1,5}$, Eric P Hoberg ${ }^{6}$ and Susan J Kutz ${ }^{1,2}$

\begin{abstract}
Background: Onchocerca cervipedis is a filarioid nematode of cervids reported from Central America to boreal regions of North America. It is found primarily in subcutaneous tissues of the legs, and is more commonly known as 'legworm'. Blackflies are intermediate hosts and transmit larvae to ungulates when they blood-feed. In this article we report the first records of $O$. cervipedis from high latitudes of North America and its occurrence in previously unrecognized host subspecies including the Yukon-Alaska moose (Alces americanus gigas) and the Grant's caribou (Rangifer tarandus granti).

Methods: We examined the subcutaneous connective tissues of the metacarpi and/or metatarsi of 34 moose and one caribou for parasitic lesions. Samples were collected from animals killed by subsistence hunters or animals found dead in the Northwest Territories (NT), Canada and Alaska (AK), USA from 2005 to 2012. Genomic DNA lysate was prepared from nematode fragments collected from two moose. The nd5 region of the mitochondrial DNA was amplified by PCR and sequenced.

Results: Subcutaneous nodules were found in 12 moose from the NT and AK, and one caribou from AK. Nematodes dissected from the lesions were identified as Onchocerca cervipedis based on morphology of female and male specimens. Histopathological findings in moose included cavitating lesions with multifocal granulomatous cellulitis containing intralesional microfilariae and adults, often necrotic and partially mineralized. Lesions in the caribou included periosteitis with chronic cellulitis, eosinophilic and lymphoplasmacytic infiltrate, and abundant granulation associated with intralesional adult nematodes and larvae. Sequences of the nd5 region (471 bp), the first generated for this species, were deposited with Genbank (JN580791 and JN580792). Representative voucher specimens were deposited in the archives of the United States National Parasite Collection.

(Continued on next page)
\end{abstract}

\footnotetext{
* Correspondence: gui.verocai@ucalgary.ca

${ }^{1}$ Department of Ecosystem and Public Health, Faculty of Veterinary Medicine, University of Calgary, 3330 Hospital Drive NW, Calgary, AB T2N 4N1, Canada Full list of author information is available at the end of the article
} 
(Continued from previous page)

Conclusions: The geographic range of $O$. cervipedis is broader than previously thought, and extends into subarctic regions of western North America, at least to latitude $66^{\circ} \mathrm{N}$. The host range is now recognized to include two additional subspecies: the Yukon-Alaska moose and Grant's caribou. Accelerated climate change at high latitudes may affect vector dynamics, and consequently the abundance and distribution of 0 . cervipedis in moose and caribou. Disease outbreaks and mortality events associated with climatic perturbations have been reported for other filarioids, such as Setaria tundra in Fennoscandia, and may become an emerging issue for O. cervipedis in subarctic North America.

Keywords: Alces, Caribou, Legworm, North America, Onchocerca cervipedis, Moose, Rangifer, Subarctic, Vector-borne diseases

\section{Background}

Onchocerca cervipedis Wehr \& Dikmans, 1935 (Nematoda; Onchocercidae), is a widespread filarioid parasite of cervids, reported from Costa Rica to boreal regions of North America [1-4]; it is also considered as a typical parasite in cervids across the Holarctic [5]. It was first described in white-tailed deer (Odocoileus virginianus) and black-tailed deer (Odocoileus hemionus columbianus) from Montana and British Columbia in 1935 [6]. A filarioid found in the pronghorn (Antilocapra americana) in 1934 was subsequently assigned to this species [7], and there have since been several reports in species of Odocoileus [8-11] throughout Canada and the USA (excluding Alaska), and a single report in white-tailed deer from Costa Rica, Central America [1]. It has also been reported in the wapiti (Cervus canadensis) from Idaho [8]. Published reports of O. cervipedis in moose have been restricted to the subspecies Alces americanus andersoni in British Columbia [12], southern Alaska [4] and northern Alberta [2,13]. Gross lesions consistent with infection, however, have been observed in YukonAlaska moose (Alces americanus gigas) from the Yukon (Philip Merchant, pers. comm.). A single report in Rangifer is from a woodland caribou (Rangifer tarandus caribou) from Tweedsmuir Park, BC [3].

Onchocerca cervipedis generally affects subcutaneous tissues of hindquarters from the tibio-tarsal joint to hoof, and thus is more commonly known as 'legworm' or 'footworm'. The presence of $O$. cervipedis rarely cause clinical signs; however, massive infections can cause swelling and hoof damage in species of Odocoileus, which may increase susceptibility to predation $[8,9]$. Clinical disease has not been reported in caribou, nor has associated histopathology been described from any of its multiple hosts.

Blackflies (Diptera: Simuliidae) act as intermediate hosts $(\mathrm{IH})$, transmitting the parasite to ungulates during blood meals. Studies on black fly vectors of this filarioid are scarce in the literature. In California, Prosimulium impostor is the only known IH responsible for deer infection [14]. Simulium decorum and Simulium venustum are demonstrated as $\mathrm{IH}$ in northeastern Alberta, and other simuliid species have been reported feeding on moose; however, their competence as $\mathrm{IH}$ are not known [13].

Disease emergence associated with climatic conditions and new host associations has been reported for related arthropod-borne filarioids of ungulates at higher latitudes. For example, peritonitis epizootics caused by Setaria tundra in reindeer were linked to unusually warm climatic conditions in Fennoscandia [15,16]. Emergence of Onchocerca skrjabini (= O. tarsicola) in reindeer (Rangifer tarandus) in Sweden during the late 60's was hypothesized to be caused by range expansion of the putative primary host, the red deer (Cervus elaphus) see [17]. Under current conditions of climate warming, shifts in distribution of suitable vector species and more favourable temperatures for both parasite and vector development and survival, have led to the geographic expansion and/or amplification in endemic areas of various arthropod-transmitted pathogens. Both phenomena can result in disease emergence [16,18-21]. Therefore, a better understanding of the diversity, host and geographic range, and ecology of these parasites is warranted.

Passive and active disease surveillance efforts, together with hunter-based wildlife health monitoring efforts [22] from 2005 to 2012, led to the discovery of O. cervipedis in moose and caribou across higher latitudes of Canada and Alaska. The objective of this paper is to report on these discoveries and present associated molecular and histopathological findings.

\section{Methods}

\section{Sampling}

Opportunistic collections: Between 2005 and 2012, incidental nodular lesions on the metacarpus and/or metatarsus were detected and collected during skinning of hunted moose (A. a. gigas and A. a. andersoni) from the Northwest Territories (NT), Canada, and Alaska (AK), and caribou ( $R$. $t$. granti) sampled during the Mulchatna herd health survey by the Alaska Department of Fish 
and Game (Table 1). Alces a. gigas is the moose subspecies which ranges in AK, Yukon and the Mackenzie Mountains, NT and has a short seasonal migration of up to $196 \mathrm{~km}$ [see 23]. Alces a. andersoni is distributed throughout central Canada, and north-central USA, extending north through much of the boreal, taiga and tundra areas of mainland NT, and parts of Nunavut. Individuals of this subspecies do not tend to migrate and have overlapping home ranges [24]. In contrast, caribou of the Mulchatna herd range over $69,457 \mathrm{~km}^{2}$ (range $=54,337-78,513 \mathrm{~km}^{2}, 1997-1998$ estimate) in southwestern AK (Figure 1) and have an annual seasonal migration between winter and summer range [25].

Submitted metacarpi and metatarsi were examined for lesions and these were dissected and nematodes collected, frozen, and subsequently preserved in $70 \%$ ethanol for morphological and molecular identification. A subset of tissues containing lesions was preserved in $10 \%$ formalin and processed routinely for histopathological examination.

Moose health survey (Sahtu, NT): Between 2010 and 2012, during a subsistence hunter-based health survey on moose from the Sahtu Settlement Area, NT, the left leg (metatarsus to hoof) on each animal was collected to evaluate body condition (marrow bone). Subcutaneous tissues of the metatarsals from a total of 28 moose, 26 from the Fort Good Hope area and 2 from Deliné area were examined for lesions (Table 1). Tissues containing lesions were collected and examined using a dissecting microscope.

\section{Parasitological examinations}

Female and/or male nematodes collected from moose were cleared in lactophenol or phenol-alcohol, examined microscopically, and identified according to the literature for the species $[6,26]$ and compared with all other Onchocerca species infecting cervids [27-30]. Tissues from one of the Tabasco Lake adult moose (W76-09Ta) and the Mulchatna caribou were prepared for histology: embedded in paraffin, sectioned and subsequently stained with haematoxylin-eosin.

Genomic DNA (gDNA) lysate was prepared from nematode fragments collected from Kelly Lake moose and Tabasco Lake moose. Briefly, fragments of $2-4 \mathrm{~mm}$ were individually transferred into $0.2 \mathrm{~mL}$ tubes containing $5 \mu \mathrm{L}$ of deionized water. To each tube was added $50 \mu \mathrm{L}$ of lysis buffer $(0.4 \mathrm{mg} / \mathrm{mL}$ of proteinase $\mathrm{K})$ and these were incubated at $60^{\circ} \mathrm{C}$ for $60 \mathrm{~min}$, followed by $95^{\circ} \mathrm{C}$ for $15 \mathrm{~min}$. DNA lysate was diluted $1: 20$ in DNase RNase free $d d \mathrm{H}_{2} \mathrm{O}$. PCR was performed using primers ND5OvA (5'-TTGGTTGCCTAAGGCTATGG-3') and ND5OvC (5'-CCCCTAGTAAACAACAAACCACA-3') targeting the $n d 5$ region of mitDNA, using a protocol modified from the literature [31]. PCR amplification was performed in $25 \mu \mathrm{L}$ reactions containing $16.7 \mu \mathrm{L}$ of water, $2.5 \mu \mathrm{L}$ of $10 \mathrm{x}$ PCR buffer, $2.0 \mu \mathrm{L}$ of $\mathrm{MgCl}_{2}, 0.5 \mu \mathrm{L}$ of $10 \mathrm{mmol}$ dNTPs, $0.5 \mu \mathrm{L}(40 \mathrm{pmol})$ of each primer, $0.3 \mu \mathrm{L}$ of Taq DNA polymerase, and $2 \mu \mathrm{L}$ of DNA template. Amplification conditions consisted of an initial $2 \mathrm{~min}$ denaturation at $95^{\circ} \mathrm{C}$, followed by 35 cycles of $95^{\circ} \mathrm{C}$ for

Table 1 Records of $O$. cervipedis in moose and caribou from the Northwest Territories and Alaska

\begin{tabular}{|c|c|c|c|c|c|c|c|}
\hline \multirow{2}{*}{$\begin{array}{l}\text { Host/ } \\
\text { Animal ID }\end{array}$} & \multirow[t]{2}{*}{ Host subspecies } & \multirow{2}{*}{$\begin{array}{l}\text { Date } \\
\text { collected }\end{array}$} & \multirow{2}{*}{$\begin{array}{l}\text { Age class/ } \\
\text { Sex }\end{array}$} & \multirow[t]{2}{*}{ Herd/Location } & \multirow[t]{2}{*}{ Coordinates } & \multicolumn{2}{|c|}{ Accession numbers } \\
\hline & & & & & & USNPC & GenBank \\
\hline \multicolumn{8}{|l|}{ Moose - AK } \\
\hline $2005-176$ & Alces a. gigas & Sept, 2005 & Adult male & Tok River, East Central AK & $63^{\circ} 10^{\prime} 00.47^{\prime \prime} \mathrm{N} 143^{\circ} 05^{\prime} 09.75^{\prime \prime} \mathrm{W}^{\S}$ & 104120 & - \\
\hline 2006-185 & Alces a. gigas & Sept, 2006 & Adult male & Palmer area, Southcentral AK & $61^{\circ} 24^{\prime} 39.96 " \mathrm{~N} 150^{\circ} 19^{\prime} 22.80^{\prime \prime} \mathrm{W}$ & 104119 & - \\
\hline 2011-131 & Alces a. gigas & Sept, 2011 & Adult & Salcha, Interior AK & $63^{\circ} 10^{\prime} 00.47^{\prime \prime} \mathrm{N} 143^{\circ} 05^{\prime} 09.75^{\prime \prime} \mathrm{W}^{\S}$ & 105387 & - \\
\hline \multicolumn{8}{|l|}{ Moose - NT } \\
\hline UC187 & Alces $a$. andersoni & June, 2007 & Adult male & Kelly Lake, NT & $65^{\circ} 26^{\prime} 7^{\prime \prime} \mathrm{N} 126^{\circ} 10^{\prime} 40^{\prime \prime} \mathrm{W}^{\S}$ & 104778 & JN580791 \\
\hline W76-09Ta & Alces a. gigas & Sept, 2009 & Adult male & Tabasco Lake, NT & $65^{\circ} 17^{\prime} 00^{\prime \prime} \mathrm{N} 131^{\circ} 7^{\prime} 7^{\prime \prime} \mathrm{W}$ & 103495 & JN580792 \\
\hline W76-09Tb & Alces a. gigas & Sept, 2009 & Calf & Tabasco Lake, NT & $65^{\circ} 17^{\prime} 00^{\prime \prime N} 131^{\circ} 7^{\prime} 7^{\prime \prime} \mathrm{W}$ & 103495 & - \\
\hline WT-05 & Alces $a$. andersoni & Dec, 2010 & Adult & Ramparts River, NT & $66^{\circ} 06^{\prime} 20^{\prime \prime} \mathrm{N} 129^{\circ} 01^{\prime} 17^{\prime \prime} \mathrm{W}^{\S}$ & N/A & - \\
\hline WT-21 & Alces $a$. andersoni & Nov, 2010 & Adult & Apache Pass, NT & $65^{\circ} 43^{\prime} 16^{\prime \prime N} 127^{\circ} 53^{\prime} 32^{\prime \prime} \mathrm{W}^{\S}$ & 105702 & - \\
\hline WT-06 & Alces a. andersoni & Jan, 2011 & Adult & Hare Indian River, NT & $66^{\circ} 16^{\prime} 12^{\prime \prime} \mathrm{N} 127^{\circ} 12^{\prime} 00^{\prime \prime} \mathrm{W}^{\S}$ & 105701 & - \\
\hline WT-81 & Alces $a$. andersoni & Feb, 2011 & Adult & Willow Lake, NT & $65^{\circ} 28^{\prime} 10^{\prime \prime} \mathrm{N} 123^{\circ} 57^{\prime} 35^{\prime \prime} \mathrm{W}^{\S}$ & 105703 & - \\
\hline WT-60 & Alces $a$. andersoni & Jan, 2012 & Adult & Near Fort Good Hope, NT & $66^{\circ} 15^{\prime} 0^{\prime \prime} \mathrm{N} 128^{\circ} 37^{\prime} 0^{\prime \prime} \mathrm{W}^{\S}$ & 105779 & - \\
\hline WT-65 & Alces $a$. andersoni & Jan, 2012 & Adult & Tidia River, NT & $66^{\circ} 22^{\prime} 30^{\prime \prime} \mathrm{N} 129^{\circ} 11^{\prime} \mathrm{W}^{\S}$ & 105780 & - \\
\hline \multicolumn{8}{|l|}{ Caribou } \\
\hline 2006-061 & Rangifer t. granti & June, 2006 & Adult female & $\begin{array}{l}\text { Mulchatna herd, near Kaliganek, } \\
\text { Southwestern AK }\end{array}$ & $59^{\circ} 42^{\prime} 27.50^{\prime \prime} \mathrm{N} 157^{\circ} 18^{\prime} 36.33^{\prime \prime} \mathrm{W}^{\S}$ & 100427 & - \\
\hline
\end{tabular}

${ }^{\S}$ Approximate geographic coordinates. 


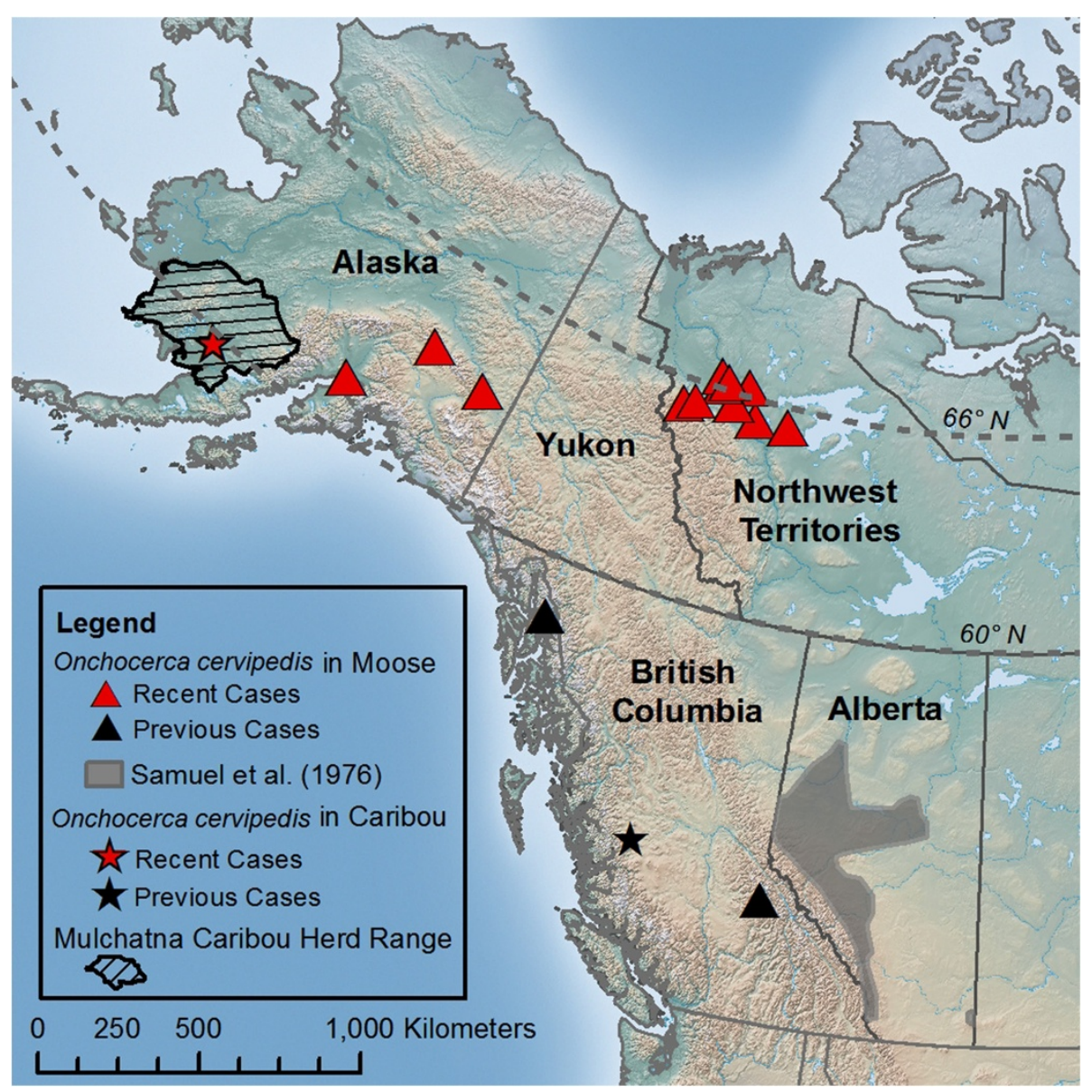

Figure 1 Reports of $O$. cervipedis from the present study and previous northernmost reports in northwestern North America.

$1 \mathrm{~min}, 50^{\circ} \mathrm{C}$ for $45 \mathrm{~s}$, and $72^{\circ} \mathrm{C}$ for $30 \mathrm{~s}$. A final extension of $72^{\circ} \mathrm{C}$ for $5 \mathrm{~min}$ was followed by cooling to $4^{\circ} \mathrm{C}$. Reagent-only reactions were used as negative controls.

PCR products were sequenced directly using ND5OvA and $\mathrm{ND} 5 \mathrm{OvC}$ primers using BigDye Terminator Cycle Sequencing (Applied Biosystems). Sequences were edited using FinchTV 1.4.0 and MEGA version 5 [32]. BLAST searches were used to compare the resulting sequences to those available in GenBank.

\section{Results}

Onchocerca cervipedis were recovered from subcutaneous nodular lesions from 12 moose in Alaska and NT and one caribou in Alaska (Table 1, Figure 1). Lesions compatible with those caused by $O$. cervipedis were found in $21.4 \%(6 / 28)$ of the examined moose legs from the Sahtu Settlement Area, NT, subsistence hunt and nematodes were found in five nodules out of six examined.

Characteristic gross lesions could only be observed after the metatarsals were skinned. Grossly, subcutaneous nodules were firm, generally round to ovoid but a few were indistinct in form, and ranged from $2-5 \mathrm{~mm}$ in length. On the cut surface, a yellowish friable material and filarioid nematodes were observed, surrounded by thick fibrous connective tissue. Histologically, in moose there were cavitating lesions with multifocal granulomatous cellulitis containing intralesional microfilariae and adults. These were characterized by presence of cuticle with thick transverse ridges and coelomyarian musculature and were often necrotic and partially mineralized (Figure 2a,b). Material from caribou demonstrated chronic periosteitis and cellulitis, eosinophilic and lymphoplasmacytic infiltrate (Figure 3). The inflammatory infiltrate was composed of numerous eosinophils, lymphocytes, and plasma cells admixed with prominent neovasculation and fibroplasia, interpreted as granulation tissue.

Nematodes were identified as O. cervipedis, based on morphological characteristics of female (cuticular pattern, vulva-head distance, esophagus length) and male (spicule length and ratio) nematodes. Specimens were deposited in the US National Parasite Collection, USDA (Table 1; Figure 1). 
Sequences of the $n d 5$ region of the mitDNA (471bp) were the first generated for O. cervipedis and were deposited in GenBank under accession numbers JN580791 and JN580792 (Table 1). These two sequences differed between each other by a single nucleotide $(99 \%$ similarity). BLAST comparisons revealed $88-93 \%$ of similarity with sequences from other species within the genus Onchocerca.

\section{Discussion}

\section{Distribution}

Our findings demonstrate a considerably broader geographic range for $O$. cervipedis, extending into subarctic western North America, at least to latitudes of $66^{\circ} \mathrm{N}$. Together with anecdotal reports of Onchocerca sp. in moose from the Yukon Territory (P. Merchant, Pers. Comm.), our results suggest a continuous distribution of $O$. cervipedis in the northern boreal forest regions of western North America. Additionally, we provide two new host records for $O$. cervipedis: the Yukon-Alaska moose (A. a. gigas) and Grant's caribou ( $R$. t. granti), supporting contentions that this parasite is a host generalist [1-11]. Migratory behaviour of some of the host species (e.g., Mulchatna caribou and Alaskan moose), may facilitate range expansion across sometimes vast distances. Due to the opportunistic nature of our sampling and the small sample size we could not evaluate age or sex predilections. In general, adult ungulates are reported to be more frequently infected [13]; however, calves and fawns are rarely harvested and this may have biased previous conclusions.

The impact of $O$. cervipedis in moose and caribou remain unknown. Clinical disease attributed to O. cervipedis in deer is most commonly confined to distal limbs and is associated with pain, loss of digits and hoof, swelling, and ulceration with female nematodes protruding through the lesions $[8,9,33]$. Such pathology would

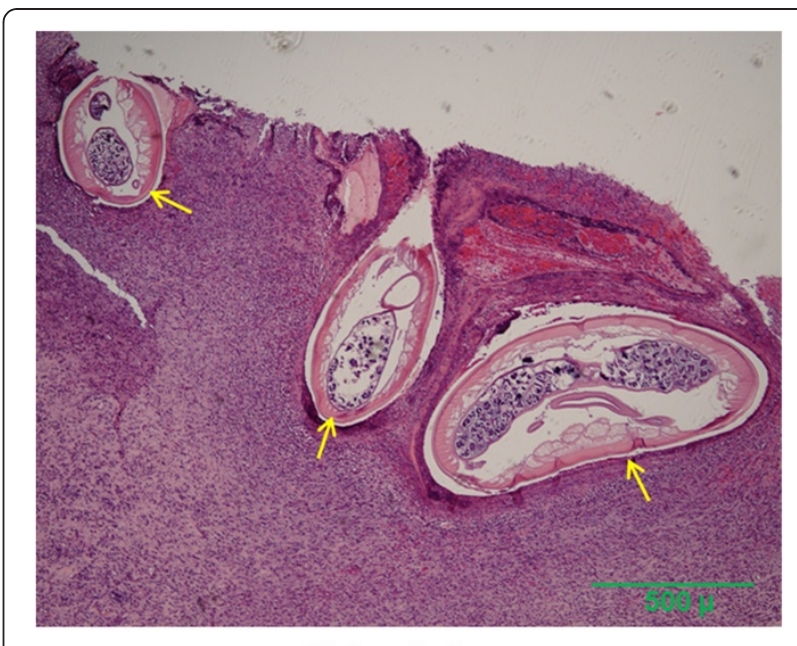

Histopathology

Figure 3 Histopathologic features of a case of $O$. cervipedis infection in a caribou from Alaska, USA. Histological section of periosteum and subcutaneous tissue nodular lesion demonstrating adult female nematodes (arrows) characterized by presence of a cuticle with thick transverse ridges and coelomyarian musculature, embedded in granulation tissue. HE stain (100x).

certainly affect animal mobility, and interference in normal activities may make clinically affected animals easier prey to both predators and hunters [8]. In contrast, we found $O$. cervipedis to be fairly common in moose and its occurrence may be characterized as an incidental finding with minimal pathology in 'healthy' moose harvested for subsistence at higher boreal latitudes of North America. The nodules in moose and the caribou were typically found along the metatarsus or metacarpus, and caused a mild to moderate local inflammatory reaction. In these hosts, parasite localization may also affect locomotion but the distal limbs and joints are not affected. There are, however, a few reports of clinical disease, with Onchocerca sp. associated with open sores
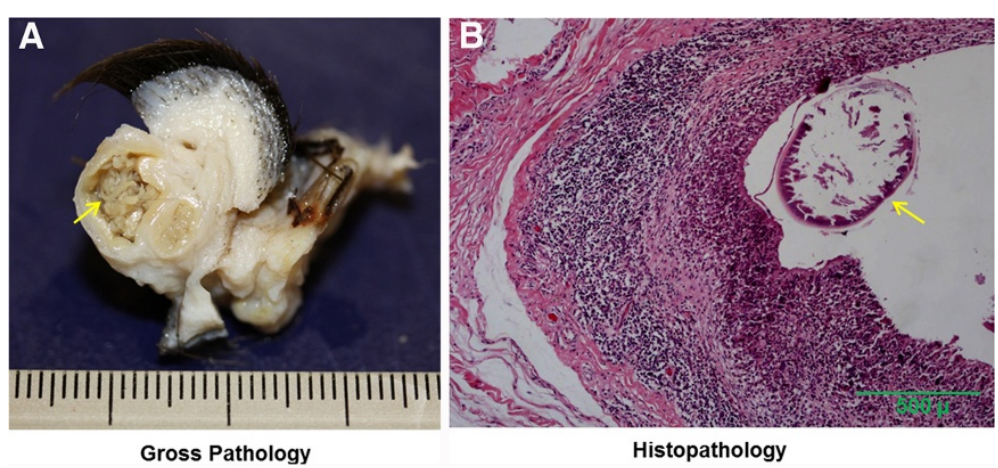

Figure 2 Gross and histologic changes in a case of $O$. cervipedis infection in a moose (W76-09Ta) from Northwest Territories, Canada.

A) Cut surface of a subcutaneous nodule surrounded by a thick connective tissue capsule and containing a yellowish, friable material and intralesional O. cervipedis adult nematodes (arrow); B) Histological transverse section of a partially mineralized dead adult nematode within a cavitating lesion lined by multinucleated giant cells, macrophages, eosinophils, lymphocytes and plasma cells. HE stain (100x). 
on the legs of moose in the Yukon (Philip Merchant, Pers. Comm.). In general, detection of sick animals in the wild may be difficult. Heavily parasitized animals with reduced mobility may be rapidly eliminated by wolf and bear predation, and therefore, the significance and extent of $O$. cervipedis in northern Canada and Alaska is difficult to establish.

\section{Related Onchocerca species}

Until recently, O. cervipedis was thought to be the only Onchocerca species parasitizing native cervids of North America. Molecular characterization of Onchocerca microfilariae from subcutaneous tissues of white-tailed deer in Northeastern USA revealed that at least one other species is present in native North American cervids [34]. In contrast, five Onchocerca species have been described infecting wild cervids in the Palearctic [27]. This is consistent with a general pattern of greater nematode species diversity in ungulates of Eurasia. This pattern is related to the historical expansion and geographic colonization of ungulate hosts and parasites, including filarioids, from Eurasia into North America over the past 2-3 Myr [e.g., 35]. However, recent studies in North America further suggest that the biodiversity of Onchocerca species from the Nearctic has been underestimated, and deserves more rigorous investigation combining comparative morphological and molecular approaches.

Regarding the broader diversity for species of Onchocerca across the Holarctic, O. cervipedis is reported from Sakha and the Altai region of Russia [see 5], although conspecificity of Eurasian and North American parasites remains to be determined. Among Palearctic species in cervids, Onchocerca alcis has been described from tendon insertions of the tibia in European moose, and seems to be most closely related to Onchocerca jakutensis (= O. tubingensis), a red deer (Cervus elaphus) parasite [27]. Other species that infect red deer are $O$. skrjabini, Onchocerca flexuosa, and Onchocerca garmsi. Onchocerca skrjabini is commonly found in reindeer in Sweden. It does not form nodules but is found free in tissues surrounding the tendons of tibio-tarsal and radio-carpal joints, and also in other parts of the body, including muzzle and shoulders [17]. Similarly, $O$. garmsi does not form nodules and it can be found free in subcutaneous tissues of the sternal region. Onchocerca flexuosa is found in subcutaneous nodules on the back, chest, and abdomen of red deer [36]. The nodular lesions caused by the Nearctic O. cervipedis in moose and reindeer seem to be more similar to those caused by O. flexuosa. Onchocerca flexuosa, however, has also been associated with necrotic foci in the liver, and to a lesser extent in kidney, myocardium, and other tissues in slaughtered Swedish reindeer. Histologically, these foci or granulomas contain larval or adult nematodes, and culture revealed Corynebacterium spp., thus constituting a relevant meat hygiene issue and resulting in discard of affected organs see [17]. A more systemic distribution of O. cervipedis has not been observed nor has the potential for secondary bacterial infection been investigated. If found this may be of food safety relevance for subsistence and other hunters.

\section{Parasite and vector ecology}

The only Simuliidae known to be involved in the transmission of $O$. cervipedis to moose in northern Alberta were Simulium decorum and Simulium venustum [13]. Both $S$. decorum/noelleri (as they are morphologically indistinguishable) and species within the S. venustum complex are present in the Mackenzie Mountains, NT $[37,38]$. Other species that feed on moose and other large ungulates, such as those in the Simulium arcticum complex and Simulium vittatum/tribulatum, also occur in the study area in the NT (D. Currie, unpublished data), but their competency as vectors for O. cervipedis is unknown. The above mentioned species and/or species-complex are also widely distributed in Alaska, and the Yukon $[39,40]$. In California, Prosimulium impostor is thought to be the only dipteran vector responsible for transmission of $O$. cervipedis to Columbian black-tailed deer [14]. Although P. impostor is not reported in our study area, a variety of other species within the genus Prosimulium are present [37,38].

Filarioid nematodes may be particularly sensitive to climatic changes both through effects on vector abundance and parasite development. In Finland, severe disease outbreaks in reindeer caused by $S$. tundra have been linked to episodes of unusually warm climatic conditions $[15,16,19]$. Under current climate warming scenarios for northern Canada and Alaska [41] we might anticipate substantial changes in the ecology, distribution, and abundance and impacts of O. cervipedis, and perhaps other filarioids, in northern ungulates [e.g., 20,42]. Climate-facilitated range expansion of the parasite may become of particular importance for naive migratory tundra caribou populations. To date, $O$. cervipedis has not been reported in these caribou, and was not found by our group despite examination of metatarsals from over 500 barrenground caribou (R. $t$. groenlandicus) across North America between 2007 and 2011 [43]. Sitka black-tailed deer (O. hemionus sitkensis), potentially sympatric with some moose populations in Alaska, may also serve as suitable definitive hosts and should be further investigated.

Some species of Onchocerca parasites of wild cervids are zoonotic. For instance, Onchocerca jakutensis, infecting red deer (Cervus elaphus) in Europe, has been the cause of nodular dermatological disease in humans [44]. This raises the possibility of zoonotic potential in other 
Onchocerca species associated to wild ungulates, such as $O$. cervipedis.

\section{Conclusions}

Climate warming is known to influence distribution and transmission dynamics of many parasitic organisms, in particular those requiring arthropod or other ectothermic species as vectors or intermediate hosts to complete their life-cycles. Our study, based on opportunistic sampling, together with the recent discovery of a potentially new species of Onchocerca in white-tailed deer in the USA, demonstrates that knowledge of species distribution and diversity in North America is incomplete. Similarly, the ecology and impacts of O. cervipedis in general, and particularly at northern latitudes, are poorly understood. These gaps in knowledge pose important limitations on our ability to anticipate how climate change may affect these host-parasite interactions in subarctic regions and the potential for northern range expansion into $R$. t. groenlandicus populations at arctic latitudes.

\section{Competing interests}

The authors declare no competing interests.

\section{Authors' contribution}

GGV lead the study and preparation of the manuscript. SJK oversaw the study and manuscript preparation. GGV and EPH did morphological identification of specimens. GGV and ML carried out the molecular genetic study, CKK, AMV, RAP, and SJK participated in acquiring data from the moose health survey in the NT. KBB, SJK, AMV, RAP, and CF acquired specimens and provided histopathologic findings from moose and caribou material from Alaska and Canada. All authors critically revised and approved the final manuscript.

\section{Acknowledgements}

This study was supported by the Faculty of Veterinary Medicine, University of Calgary ( $U$ of $C)$, and NSERC Canada International Polar Year Funding, the NWT Cumulative Impact Monitoring Program (CIMP), and the Sahtu Renewable Resources Board. The authors are thankful to Doug Currie from the Royal Ontario Museum for his contributions regarding Simuliidae fauna of northern Canada and Alaska. We thank Nathan Pamperin (Alaska Department of Fish and Game) for producing the map; and Kathy Burek Huntington (Alaska Veterinary Pathology Services) for the report on histopathology of caribou; Patricia Pillitt and Art Abrams from the USNPC, USDA, for helping with specimen deposition at USNPC; and Jesse Invik, Marianne Vervest, and loana Custelcean for assisting with leg dissections at $\mathrm{U}$ of $\mathrm{C}$. We thank Dr. Alessandro Massolo ( $\mathrm{U}$ of $\mathrm{C}$ ), for contribution to study design for sampling of moose harvested in subsistence hunts. We thank the Fort Good Hope Renewable Resource Council, participants of the Fort Good Hope community hunt in September 2009, and hunters of the Sahtu Settlement Area, NT for collaborating with sample and data collection.

\section{Author details}

'Department of Ecosystem and Public Health, Faculty of Veterinary Medicine, University of Calgary, 3330 Hospital Drive NW, Calgary, AB T2N 4N1, Canada. ${ }^{2}$ Canadian Cooperative Wildlife Health Centre, Calgary AB Canada, Faculty of Veterinary Medicine, University of Calgary, 3330 Hospital Drive NW, Calgary, AB T2N 4N1, Canada. ${ }^{3}$ Division of Wildlife Conservation, Alaska Department of Fish and Game, 1300 College Road, Fairbanks, AK 99701, USA. ${ }^{4}$ Department of Environment and Natural Resources, Government of the Northwest Territories, Norman Wells, NT, Canada. ${ }^{5}$ Present address: Department of Structure and Function, School of Veterinary Medicine, Ross University, Basseterre, St. Kitts, St. Kitts and Nevis. ${ }^{6}$ US National Parasite Collection, Agricultural Research Service, USDA, BARC East No. 1180, 10300 Baltimore Avenue, Beltsville, MD 20705, USA.
}

Received: 29 June 2012 Accepted: 15 October 2012

Published: 30 October 2012

\section{References}

1. Carreno RA, Durden LA, Brooks DR, Abrams A, Hoberg EP: Parelaphostrongylus tenuis (Nematoda: Protostrongylidae) and other parasites of white-tailed deer (Odocoileus virginianus) in Costa Rica. Comp Parasitol 2001, 68:177-184.

2. Samuel WM, Barrett MW, Lynch GM: Helminths in moose of Alberta. Can J Zool 1976, 54:307-312.

3. Low WA: Parasites of woodland caribou in Tweedsmuir Provincial Park, British Columbia. Can Field-Nat 1976, 90:189-191.

4. Williams RB, Babero BB: Onchocerca in an Alaskan moose. J Mammal 1958, 39:449-450.

5. Priadko El: Gel'minty Olenei. Alma-Ata: Izdatel'stvo Nauka Kazakhskoi SSR; 1976.

6. Wehr EE, Dikmans G: New nematodes (Filariidae) from North America ruminants. Zool Anz 1935, 110:202-208.

7. Dikmans G: Onchocerca flexuosa from the subcutaneous tissues of an antelope and subcutaneous abscesses of a deer. J Parasitol 1933, 19:1.

8. De Nio RM, West RM: The foot-worm disease in deer on the Northern Rocky Mountain Region. J For 1942, 40:540-543.

9. Herman CM, Bischoff Al: The footworm parasite of deer. California Fish and Game 1946, 32:182-190.

10. Anderson RC: The helminth and arthropod parasites of the white-tailed deer (Odocoileus virginianus): a general review. Trans R Can Soc 1962, 34:57-92.

11. Walker ML, Becklund WW: Checklist of the internal and external parasites of deer, Odocoileus hemionus and Odocoileus virginianus in the United States and Canada. Washington, DC: United States Government Printing Office; 1970.

12. Ritcey RW, Edwards RY: Parasites and Diseases of the Wells Gray Moose Herd. J Mammal 1958, 39:139-145.

13. Pledger DJ: Black flies (Diptera, Simuliidae) of the Swan Hills, Alberta as possible vectors of Onchocerca cervipedis Wehr \& Dikmans 1935 (Nematoda; Onchocercidae) in moose (Alces alces Linnaeus). University of Alberta: Department of Entomology; 1978.

14. Weinmann CJ, Anderson JR, Longhurst WM, Conolly G: Filarian worms of Columbian Black-tailed deer in California I. Observations in the vertebrate host. J Wildl Dis 1973, 9:213-220.

15. Laaksonen S, Kuusela J, Nikander S, Nylund M, Oksanen A: Outbreak of parasitic peritonitis in reindeer in Finland. Vet Rec 2007, 160:835-841.

16. Laaksonen $\mathrm{S}$, Oksanen A: Vector-borne nematodes, emerging parasites in Finnish cervids. Acta Vet Scand 2010, 52:S3.

17. Rehbinder C: Some vector borne parasites in Swedish reindeer (Rangifer tarandus tarandus L). Rangifer 1990, 10:67-73.

18. Kutz SJ, Jenkins EJ, Veitch AM, Ducrocq J, Polley L, Elkin B, Lair S: The Arctic as a model for anticipating, preventing, and mitigating climate change impacts on host-parasite interactions. Vet Parasitol 2009, 163:217-228.

19. Laaksonen S, Solismaa M, Kortet R, Kuusela J, Oksanen A: Vectors and transmission dynamics for Setaria tundra (Filarioidea; Onchocercidae), a parasite of reindeer in Finland. Parasit Vectors 2009, 2:3.

20. Hoberg EP: Invasive processes, mosaics and the structure of helminth parasite faunas. Rev Sci Tech OIE 2010, 29:255-272.

21. Tabachnick WJ: Challenges in predicting climate and environmental effects on vector-borne disease episystems in a changing world. J Exp Biol 2010, 213:946-954.

22. Brook RK, Kutz SJ, Veitch AM, Popko R, Elkin BT, Guthrie G: Fostering Community-Based Wildlife Health Monitoring and Research in the Canadian North. EcoHealth 2009, 6:266-278.

23. Mauer FJ: Moose migration: northeastern Alaska to northwestern Yukon Territory, Canada. Alces 1998, 34:75-81.

24. Stenhouse GB, Latour PB, Kutny L, MacLean N, Glover G: Productivity, survival, and movements of female moose in a low-density population Northwest Territories, Canada. Arctic 1995, 48:57-62.

25. Hinkes MT, Collins GH, Van Daele L, Kovach SD, Aderman AR, Woolington JD, Seavoy RJ: Influence of population growth on caribou herd identity, calving ground fidelity, and behavior. J Wild Manage 2005, 69:1147-1162

26. Caballero YC: Morfologia y posicion sistematica de Onchocerca cervipedis. Rev Bras Biol 1954, 4-5:557-562. 
27. Bain O, Rehbinder $\mathrm{C}$ : Nouvelle onchocerque, Onchocerca alcis n. sp., parasite de l'Élan, Alces alces, en Suède. Ann Parasitol Hum Comp 1986, 61:447-455.

28. Bain O, Schulz-Key H: Les Onchocerques du Cerf européen: Redescription d'O. flexuosa (Wedl, 1856) et description d'O. tubingensis n. sp. et $O$. tarsicola n. sp. Tropenmed Parasitol 1974, 25:437-449.

29. Bain O, Schulz-Key H: Une quatrième espèce d'onchocerque, O. garmsi $\mathrm{n}$. sp., chez le Cerf européen. Tropenmed Parasitol 1976, 27:474-478.

30. Bain O: Le genre Onchocerca: Hypothèses sur son évolution et clé dichotomique des espèces. Ann Parasitol Hum Comp 1981, 56:503-526.

31. Morales-Hojas R, Checke RA, Post RJ: Molecular systematics of five Onchocerca species (Nematoda: Filarioidea) including the human parasite, O. volvulus, suggest sympatric speciation. J Helminthol 2006, 80:281-290

32. Tamura K, Peterson D, Peterson N, Stecher G, Nei M, Kumar S: MEGA5: Molecular Evolutionary Genetics Analysis using Maximum Likelihood Evolutionary Distance, and Maximum Parsimony Methods. Mol Biol Evol 2011, 28:2731-2739.

33. Rush WM: Onchocerciasis: a new disease in the white-tailed deer of Montana. J Mammal 1935, 16:70-71.

34. McFrederick QS, Haselkorn TS, Verocai GG, Jaenicke J: Cryptic Onchocerca species infecting North American cervids, with implications for the evolutionary history of host association in Onchocerca. Parasitology, . in press.

35. Hoberg EP, Galbreath KE, Cook JA, Kutz SJ, Polley L: Northern host-parasite assemblages: History and biogeography on the borderlands of episodic climate and environmental transition. Adv Parasitol 2012, 79:1-97.

36. Wildenburg G, Plenge-Bönig A, Renz A, Fischer P, Büttner DW: Distribution of mast cells and their correlation with inflammatory cells around Onchocerca gutturosa, O. tarsicola, O. ochengi, and O. flexuosa. Parasitol Res 1997, 83:109-120.

37. Currie DC, Adler PH: Update on a survey of the black flies (Diptera: Simuliidae) from the Northwest Territories and Nunavut project. Arctic Insect News 2000, 11:6-9.

38. Currie DC: A preliminary assessment of Subarctic black fly diversity (Diptera: Simuliidae) in Norman Wells and environs, Northwest Territories. Newsletter of the Biological Survey of Canada (Terrestrial Arthropods) 2006, 25:18-21.

39. Currie DC: Blackflies of the Yukon. In Insects of the Yukon. Edited by Danks HV, Downes JA. Ottawa: Biological Survey of Canada (Terrestrial Arthropods); 1997:1034.

40. Adler PH, Currie DC: Barbarians at the gate: biting flies of Beringia. Alaska Park Sci 2008, 7:28-31.

41. IPCC: Summary for Policymakers. Climate Change 2007: The Physical Science Basis. In Summary for Policymakers. Climate Change 2007. Edited by The Physical Science Basis. Cambridge and New York: Cambridge University Press; 2007.

42. Hoberg EP, Polley L, Jenkins EJ, Kutz SJ: Pathogens of domestic and free-ranging ungulates: Global climate change in temperate to boreal latitudes across North America. Rev Sci Tech OIE 2008, 27:511-528.

43. Kutz SJ, Ducrocq J, Cuyler C, Elkin B, Gunn A, Kolpashikov L, Russell D, White R: Standardized monitoring of Rangifer health during International Polar Year. Rangifer, in press.

44. Koehsler M, Soleiman A, Aspock H, Auer H, Walochnik J: Onchocerca jakutensis filariasis in humans. Emerg Infect Dis 2007, 13:1749-1752.

doi:10.1186/1756-3305-5-242

Cite this article as: Verocai et al:: Defining parasite biodiversity at high latitudes of North America: new host and geographic records for Onchocerca cervipedis (Nematoda: Onchocercidae) in moose and caribou. Parasites \& Vectors 2012 5:242.

\section{Submit your next manuscript to BioMed Central and take full advantage of:}

- Convenient online submission

- Thorough peer review

- No space constraints or color figure charges

- Immediate publication on acceptance

- Inclusion in PubMed, CAS, Scopus and Google Scholar

- Research which is freely available for redistribution

Submit your manuscript at www.biomedcentral.com/submit
C Biomed Central 